\title{
Synthesis, structural characterisation and biological studies of new mononuclear platinum(II) complexes with sterically hindered heterocyclic ligands
}

\author{
S. Rubino ${ }^{a}$, P. Portanova ${ }^{b}$, F. Giammalva ${ }^{a}$, M.A. Girasolo ${ }^{a}$, S. Orecchio ${ }^{\text {, G. G. Calvaruso }}{ }^{\text {b }}$, G.C. Stocco ${ }^{\text {a,* }}$ \\ a Dipartimento di Chimica Inorganica ed Analitica “S. Cannizzaro", Università degli Studi di Palermo, Viale delle Scienze, Parco d'Orleans, 90128 Palermo, Italy \\ ${ }^{\mathrm{b}}$ Dipartimento di Scienze Biochimiche, Policlinico, Università degli Studi di Palermo, Via del Vespro 129, 90127 Palermo, Italy
}

\section{A R T I C L E I N F O}

\section{Article history:}

Received 12 May 2010

Received in revised form 20 December 2010

Accepted 18 January 2011

Available online 31 January 2011

\section{Keywords:}

Heterocyclic ligands

Platinum complexes

Antitumor activity

\begin{abstract}
A B S T R A C T
Three novel cisplatin analogues were synthesized, designed according to an approach which violates the "classical" structure-activity relationship, by replacing the diamine ligands with a planar $\mathrm{N}$ donor heterocycle giving a sterically hindered complex. Moreover, the sterical hindrance of antitumor drug candidates potentially makes them less susceptible to deactivation by sulphur-containing proteins and helping to overcome resistance mechanisms. The resulting mononuclear complexes of sterically hindered polidentate heterocyclic $\mathrm{N}$ ligands $[\mathrm{PtCl}(\mathrm{bbp})] \mathrm{Cl}(\mathbf{1})$ [ $\mathrm{bbp}=2,6$-bis(2-benzimidazolyl)pyridine], $\left[\mathrm{PtCl}_{2}(\mathrm{dptdn})\right]\left(\mathrm{H}_{2} \mathrm{O}\right)$ (2) $\quad$ dptdn = sodium 5,6-diphenyl-3-(2'-pyridyl)-1,2,4-triazine-4" $4^{\prime \prime \prime}$-disulfonate] and $[(\mathrm{dptdn})(\mathrm{dpt}) \mathrm{Pt}] \mathrm{Cl}_{2}\left(\mathrm{H}_{2} \mathrm{O}\right)(3)$ [dpt = 5,6-diphenyl-3-(2'-pyridyl)-1,2,4-triazine] have been prepared and structurally characterised. Both neutral and ionic complexes are present, with monofunctional (1) and bifunctional $\mathrm{Pt}(\mathrm{II})$ moieties (2) and coordinatively saturated $\mathrm{Pt}(\mathrm{II})$ ions in the mixed ligand complex (3), whose size and shape enable them to behave as novel scaffolds for DNA binding. All complexes were tested "in vitro" for their biological activity on human HT29 colorectal carcinoma and HepG2 hepatoma cells. The complexes (1) and (3), endowed with a positive charge, showed a potent cytotoxic activity and reduced cell viability with an efficacy higher than that of cisplatin; whilst the neutral bifunctional compound (2) was inactive. IC50 values have been calculated for the active compounds. The cytotoxic effects were confirmed by the accumulation of treated cells in subG0/G1 phase of cell cycle, by the loss of mitochondrial potential $\left(\Delta \psi_{\mathrm{m}}\right)$ and by the chromatin condensation or fragmentation observed by means of fluorescence microscopy after Hoechst 33258 nuclear staining. A study on intracellular platinum uptake in HT29 cell line has been also performed and data obtained strongly suggest that the cytotoxicity of new tested complexes reported in this work is based on a different pharmacodynamic pattern with respect to cisplatin.
\end{abstract}

(ㄷ) 2011 Elsevier B.V. All rights reserved.

\section{Introduction}

Huge limitations due to lack of activity against tumours with inherent or acquired resistance to cisplatin along with a variety of adverse effects, such as nephrotoxicity, myelosupression, and severe emesis have been observed [1,2]. New approaches in design and development of platinum complexes to overcome drug resistance and increase the range of drug activity include replacement of chloride ligands with various leaving groups, use of modified amine and non-amine ligands to form polynuclear platinum complexes and combination therapy using both platinum and ruthenium has been advanced [3]. Cisplatin stands as a milestone of biological activity of metal ions and the usefulness of providing more advances in this prominent field is not farfetched.

Interest in mononuclear cisplatin analogues has improved as a strategy for selective delivery of platinum anticancer agents.

\footnotetext{
* Corresponding author. Tel.: +39 091 6575522; fax: +39 091427584 .

E-mail address: stoccogc@unipa.it (G.C. Stocco).
}

Tethering carbohydrate moieties to the platinum centre [1], was designed to target liver cancer because of galactose receptors on the surface of liver parenchymal cells. DNA targeting moieties such as DNA intercalators used as platinum carriers may also be a new strategy, possibly leading to a broadened spectrum activity [4] and exalting platinum intracellular uptake. Pt(II) complexes with polypyridyl 2-(2-benzimidazolyl)pyridine ligands [5], heterocycles endowed with hydrophobic properties, have been reported and an increase of hydrophobicity around the drug-DNA binding site has been assessed. The presence of $\mathrm{NH}$ containing moieties in these complexes can originate H-bonding interactions towards DNA, validating the well-established structure-activity relationships which claims the necessity of at least one $\mathrm{NH}$ moiety within the ligand for H-bonding interactions towards DNA. In this paper we report a platinum complex of this ligand which is very active towards two cancer cell lines. A cisplatin analogue with 5,6-diphenyl-3(2'-pyridyl)-1,2,4-triazine-4", $4^{\prime \prime \prime}$-disulfonate, lacking the $\mathrm{N}-\mathrm{H}$ group, has been obtained, which is inactive. The same ligand along with 5,6-diphenyl-3-(2'-pyridyl)-1,2,4-triazine was used to afford 
a mixed ligand complex which appears to be very active towards the cited cell lines. The antitumor activity of the complexes lacking a $\mathrm{NH}$ containing moiety may be the concomitant intercalation and the presence of increased steric hindrance around the coordinated platinum atom as the complex cannot be easily inactivated by biomolecules as S-containing proteins before binding to DNA [6]. Platinum(II) complexes with N-donor aromatic 3-(pyridyl-2'-yl)1,2,4-triazine ligands have been reported to possess great potential as anti-HIV microbicides [7]. Amongst the complexes presented in this work the one which bears the closest similarity to cisplatin is [ $\left.\mathrm{PtCl}_{2}(\mathrm{dptdn})\right] 2$ which is neutral and bifunctional, to our dismay being inactive, whilst complexes $\mathbf{1}$ and $\mathbf{3}$ appear to be endowed with very high biological activity.

\section{Experimental}

\subsection{Materials and methods}

Potassium tetrachloro platinate(II) and the ligands sodium 5,6diphenyl-3-(2'-pyridyl)-1,2,4-triazine-4" $4^{\prime \prime \prime}$-disulfonate (dptdn) and 2,6-bis(2-benzomidazolyl)pyridine (bbp) were purchased from Aldrich.

Syntheses were performed with exclusion of moisture and direct light. Compounds were analysed for $\mathrm{C}, \mathrm{H}, \mathrm{N}$ at the Laboratorio di Microanalisi (Università degli Studi di Padova, Italy), chlorine was determined by potentiometric titration with standard silver nitrate after combustion in pure oxygen according to Schöninger [8].

Thermogravimetric measurements were performed from room temperature to $500{ }^{\circ} \mathrm{C}$, with a Mettler TA-4000 system operating in a pure nitrogen atmosphere. The IR spectra were recorded, as Nujol mulls, with a Model Spectrum ONE Perkin-Elmer Fourier Transform Instrument. Conductivity measurements for $10^{-3} \mathrm{M}$ solutions in DMSO were obtained with a Crison GLP 31 Model conductometer. Conductivity measurements on freshly prepared samples showed no evidence of significant irreversible solvolysis of platinum groups since only the ionic complexes $\mathbf{1}$ and $\mathbf{3}$ showed conductivity. The determination of potassium and platinum contents were obtained using a flame atomic spectrometer Perkin-Elmer 372 and the reported value is the average of four independent measurements. Platinum up-take determination was performed with an graphite furnace atom absorption spectrometer (GFAA) from Perkin-Elmer. A mechanistic study of mode of action of the complexes in water (kinetics of hydrolysis) was prevented by their insolubility in water.

The very poor solubility of complexes made it necessary to record the NMR spectra in DMSO- $\mathrm{d}_{6} 1 \mathrm{D}$ and $2 \mathrm{D}{ }^{1} \mathrm{H}$ and ${ }^{13} \mathrm{C}\left\{{ }^{1} \mathrm{H}\right\}$ NMR spectra for the Pt(II) derivatives were obtained at $298 \mathrm{~K}$ with Bruker Avance 300 instrument operating at $300 \mathrm{MHz}$ for ${ }^{1} \mathrm{H}$ and at $63 \mathrm{MHz}$ for ${ }^{13} \mathrm{C}$, in DMSO- $\mathrm{d}_{6}$ with tetramethylsilane (TMS) as the internal standard; furthermore, to facilitate the assignments, ${ }^{1} \mathrm{H}-{ }^{1} \mathrm{H}$ COSY (H,H correlated spectroscopy) experiments were carried out.

The most interesting feature of the NMR spectra is the indication of which sites are involved in platination. Assignment of resonances was based on literature data [9-11] and are in good agreement with the proposed structure. The solvated complex 1 presented a dismally low solubility even in DMSO- $\mathrm{d}_{6}$ which prevented the acquisition of ${ }^{13} \mathrm{C}$ NMR spectra.

\subsection{Chemical synthesis}

\subsubsection{Synthesis of $[\mathrm{PtCl}(\mathrm{bbp})] \mathrm{Cl}$ complex (1)}

An aqueous solution of $\mathrm{K}_{2} \mathrm{PtCl}_{4}(0.8317 \mathrm{~g}, 2 \mathrm{mmol})$ was treated with a solution of 2,6-bis(2-benzimidazolyl)pyridine (bbp)
( $0.6256 \mathrm{~g}, 2 \mathrm{mmol})$ obtained by using a mixture of ethanol $(5 \mathrm{ml})$ e $\mathrm{H}_{2} \mathrm{O}(20 \mathrm{ml})$. The ligand was sparingly soluble in the mixed solvent so $\mathrm{NaOH} 0.1 \mathrm{M}$ was added and the $\mathrm{pH}$ was carried to 8 . The mixture was maintained under reflux for four days in the dark. The red-brown solid complex 1 was filtered, washed with water, methanol and dried over $\mathrm{P}_{4} \mathrm{O}_{10}$. Yield: 70\%. Anal. Calc. for $\mathrm{C}_{19} \mathrm{H}_{13} \mathrm{~N}_{5} \mathrm{PtCl}_{2}$ : C, 39.53; H, 2.27; N, 12.13; Cl, 12.28, Pt, 33.79. Found: C, 40.00; H, 2.53; N, 12.50; Cl, 12.71, Pt, 34.00\%. Melting point: $>350{ }^{\circ} \mathrm{C}$ (decomp.). The complex is sparingly soluble in DMSO.

Conductivity measurements of the complex for a $10^{-3} \mathrm{M}$ solution in DMSO afforded a value of $\Lambda_{\mathrm{M}}=34.86 \Omega^{-1} \mathrm{~cm}^{2} \mathrm{~mol}^{-1}$ which was consistent with a $1: 1$ electrolyte [12].

IR $\left(\mathrm{cm}^{-1}\right)$ selected bands: $318 \mathrm{~cm}^{-1} v(\mathrm{Pt}-\mathrm{Cl}), 3500-3065 \mathrm{~cm}^{-1}$ $v(\mathrm{~N}-\mathrm{H})$.

${ }^{1} \mathrm{H}$ NMR spectrum for free ligand bbp ( $\left.\delta \mathrm{ppm}\right): 13.06(\mathrm{~s}, 2 \mathrm{H}, \mathrm{N}-$ $\mathrm{H}), 8.42\left(\mathrm{~d}, 2 \mathrm{H}, \mathrm{H}_{\mathrm{F}}-\mathrm{H}_{\mathrm{H}}\right), 8.23\left(\mathrm{t}, 1 \mathrm{H}, \mathrm{H}_{\mathrm{G}}\right), 7.82\left(\mathrm{~d}, 4 \mathrm{H}, \mathrm{H}_{\mathrm{A}}-\mathrm{H}_{\mathrm{D}}\right), 7.40$ $\left(\mathrm{m}, 4 \mathrm{H}, \mathrm{H}_{\mathrm{B}}-\mathrm{H}_{\mathrm{C}}\right) .{ }^{1} \mathrm{H}$ NMR spectrum for the complex 1: 10.16 (s, $2 \mathrm{H}, \mathrm{N}-\mathrm{H}), 8.40\left(\mathrm{~d}, 2 \mathrm{H}, \mathrm{H}_{\mathrm{F}}-\mathrm{H}_{\mathrm{H}}\right), 8.30\left(\mathrm{dd}, 1 \mathrm{H}, \mathrm{H}_{\mathrm{G}}\right), 7.80\left(\mathrm{q}, 4 \mathrm{H}, \mathrm{H}_{\mathrm{A}}-\right.$

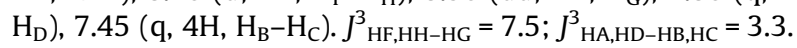

\subsubsection{Synthesis of $\left[\mathrm{PtCl}_{2}(\mathrm{dptdn})\right]\left(\mathrm{H}_{2} \mathrm{O}\right)$ complex (2) and $[(\mathrm{dptdn})(\mathrm{dpt}) \mathrm{Pt}] \mathrm{Cl}_{2}\left(\mathrm{H}_{2} \mathrm{O}\right)(\mathbf{3})$}

Complex 2: A slight excess of $\mathrm{K}_{2} \mathrm{PtCl}_{4}(0.415 \mathrm{~g}, 1.00 \mathrm{mmol})$ in water was added dropwise with stirring to a solution of sodium 5,6-diphenyl-3-(2'-pyridyl)-1,2,4-triazine-4", $4^{\prime \prime \prime}$-disulfonate (dptdn) $(0.4705 \mathrm{~g}, 0.9145 \mathrm{mmol})$ in $\mathrm{H}_{2} \mathrm{O}(25 \mathrm{~mL})$, under reflux for $24 \mathrm{~h}$ in the dark after addition of $1 \mathrm{ml} \mathrm{HCl} 0.969 \mathrm{M}$. A brown solid complex 2 was filtered, washed with ethanol and dried over $\mathrm{P}_{4} \mathrm{O}_{10}$. Yield: 80\%. Anal. Calc. for $\mathrm{C}_{20} \mathrm{H}_{15} \mathrm{~N}_{4} \mathrm{O}_{7} \mathrm{~S}_{2} \mathrm{PtCl}_{2} \mathrm{~K}$ : C, 30.31; $\mathrm{H}, 1.91 ; \mathrm{N}$, 7.07; S, 8.09; Cl, 8.95; K, 4.93, Pt 24.61. Found: C, 29.95; H, 1.58; $\mathrm{N}, 7.04 ; \mathrm{S}, 8.59 \mathrm{Cl}, 8.55, \mathrm{~K}, 5.31$; Pt 25.10\%. Melting point: $>350^{\circ} \mathrm{C}$ (decomp.). The complex is soluble in DMSO. Thermogravimetric analysis confirmed the occurrence of 1 mol of $\mathrm{H}_{2} \mathrm{O}$ per formula unit. Conductivity measurements of the complex for a $10^{-3} \mathrm{M}$ solution in DMSO afforded a value of $\Lambda_{\mathrm{M}}=6.79 \Omega^{-1} \mathrm{~cm}^{2}$ $\mathrm{mol}^{-1}$ associated with a neutral complex [12].

Complex 3: An aqueous solution of $\mathrm{K}_{2} \mathrm{PtCl}_{4} \quad(0.3112 \mathrm{~g}$, $0.749 \mathrm{mmol}$ ) was added to a mixed methanol-water solution $(5: 1, \quad \mathrm{v} / \mathrm{v})$ of 5,6-diphenyl-3-(2'-pyridyl)-1,2,4-triazine (dpt) $(0.2331 \mathrm{~g}, 0.749 \mathrm{mmol})$ and sodium 5,6-diphenyl-3-(2'-pyridyl)1,2,4-triazine- $4^{\prime \prime}, 4^{\prime \prime \prime}$-disulfonate (dptdn) (0.3670 g, $\left.0.749 \mathrm{mmol}\right)$ with stirring under reflux for $24 \mathrm{~h}$ in the dark. A greenish solid complex 3 was collected, washed with water and methanol followed by anhydrous diethyl ether, dried over $\mathrm{P}_{4} \mathrm{O}_{10}$. Yield: $90 \%$. Anal. Calc. for $\mathrm{C}_{40} \mathrm{H}_{29} \mathrm{~N}_{8} \mathrm{O}_{7} \mathrm{NaS}_{2} \mathrm{PtCl}_{2}$ : C, 44.21; $\mathrm{H}, 2.69 ; \mathrm{N}, 10.31$; $\mathrm{Cl}, 6.52$, S, 5.9; Na, 2.12, Pt, 17.95. Found: C, 43.85; H, 2.15; N, $9.81 ; \mathrm{Cl}, 6.71 ; \mathrm{S}, 5.14 ; \mathrm{Na}, 2.0 ; \mathrm{Pt}, 17.58 \%$. Melting point: $>350{ }^{\circ} \mathrm{C}$ (decomp.). The complex is sparingly soluble in DMSO. Thermogravimetric analysis confirmed the occurrence of $1 \mathrm{~mol} \mathrm{of} \mathrm{H}_{2} \mathrm{O}$ per formula unit. Conductivity measurements of the complex for a $10^{-3} \mathrm{M}$ solution in DMSO afforded a value of $\Lambda_{\mathrm{M}}=30.20 \Omega^{-1} \mathrm{~cm}^{2} \mathrm{~mol}^{-1}$ which was consistent with a $1: 2$ electrolyte [12], that could be explained with low ionic mobility of the ionic moiety.

IR $\left(\mathrm{cm}^{-1}\right)$ selected bands for complex 2: $310-360 \mathrm{~cm}^{-1} v(\mathrm{Pt}-$ $\mathrm{Cl}) ; \quad 540-550 \mathrm{~cm}^{-1} v(\mathrm{Pt}-\mathrm{N}) ; 535 \mathrm{~cm}^{-1}$ (rocking $\mathrm{SO}_{3} \mathrm{H}, \mathrm{SO}_{3}^{-}$); 1121-1215 $\mathrm{cm}^{-1}$ (stretching $\mathrm{SO}_{3} \mathrm{H}, \quad \mathrm{SO}_{3}{ }^{-}$); $\quad 1570-1609 \mathrm{~cm}^{-1}$ $v(\mathrm{C}=\mathrm{N})$ and $v(\mathrm{~N}=\mathrm{N}) .{ }^{1} \mathrm{H}$ NMR spectrum for the free ligand dptdn $(\delta \mathrm{ppm}): 8.94\left(\mathrm{~d}, 1 \mathrm{H}, \mathrm{H}_{6^{\prime}}\right) ; 8.80\left(\mathrm{~d}, 1 \mathrm{H}, \mathrm{H}_{3^{\prime}}\right) ; 8.42\left(\mathrm{dt}, 1 \mathrm{H}, \mathrm{H}_{4^{\prime}}\right)$; 8.34 and $8.21\left(\mathrm{~s}, 1 \mathrm{H}, \mathrm{SO}_{3} \mathrm{H}\right), 7.93\left(\mathrm{dt}, 1 \mathrm{H}, \mathrm{H}_{5^{\prime}}\right), 7.74-7.28(\mathrm{~m}, 10 \mathrm{H}$, phenyl protons). ${ }^{1} \mathrm{H}$ NMR spectrum for complex 2 ( $\left.\delta \mathrm{ppm}\right): 10.49$ (d, $\left.1 \mathrm{H}, \mathrm{H}_{6^{\prime}}\right) ; 9.71\left(\mathrm{~d}, 1 \mathrm{H}, \mathrm{H}_{3^{\prime}}\right), 8.93\left(\mathrm{~m}, 1 \mathrm{H}, \mathrm{H}_{4^{\prime}}\right) ; 8.76\left(\mathrm{td}, 1 \mathrm{H}, \mathrm{H}_{5^{\prime}}\right)$, $8.43\left(\mathrm{~s}, 1 \mathrm{H}, \mathrm{SO}_{3} \mathrm{H}\right), 7.94-7.69(\mathrm{~m}, 10 \mathrm{H}$, phenyl protons $)$. $J_{\mathrm{H}^{\prime}, \mathrm{H} 5^{\prime}}^{3}=4.2 ; J^{3}{ }_{\mathrm{H} 3^{\prime}, \mathrm{H} 4^{\prime}}=8.2 ; J^{3}{ }_{\mathrm{H} 5^{\prime}, \mathrm{H} 4^{\prime}}=8.0 .{ }^{13} \mathrm{C}\left\{{ }^{1} \mathrm{H}\right\}$ NMR for the complex 2 ( $\delta \mathrm{ppm}): 157.86\left(\mathrm{C}_{3}\right), 157.25\left(\mathrm{C}_{6}\right), 156.47\left(\mathrm{C}_{5}\right), 149.03$ 
$\left(C_{6^{\prime}}\right), 148.94\left(C_{2^{\prime}-3^{\prime}}\right), 147.25\left(C_{4^{\prime}}\right) 143.15\left(C_{5^{\prime}}\right), 134.82-125.49$ (phenyl carbons).

IR $\left(\mathrm{cm}^{-1}\right)$ selected bands for complex 3: $542 \mathrm{~cm}^{-1}$ (rocking $\mathrm{SO}_{3} \mathrm{H}, \mathrm{SO}_{3}{ }^{-}$), 1121-1215 $\mathrm{cm}^{-1}$ (Stretching $\mathrm{SO}_{3} \mathrm{H}, \mathrm{SO}_{3}{ }^{-}$); 1597$1630 \mathrm{~cm}^{-1} v(\mathrm{C}=\mathrm{N})$ and $v(\mathrm{~N}=\mathrm{N}) ; 3500 \mathrm{~cm}^{-1}\left(\mathrm{H}_{2} \mathrm{O}\right) .{ }^{1} \mathrm{H}$ NMR spectrum for the free ligand $\mathrm{dpt}(\delta \mathrm{ppm}): 9.01\left(\mathrm{~d}, 1 \mathrm{H}, \mathrm{H}_{6^{\prime}}\right) ; 8.74(\mathrm{~d}$, $\left.1 \mathrm{H}, \mathrm{H}_{3^{\prime}}\right), 8.28\left(\mathrm{dt}, 1 \mathrm{H}, \mathrm{H}_{4^{\prime}}\right) ; 8.83\left(\mathrm{~m}, 1 \mathrm{H}, \mathrm{H}_{5^{\prime}}\right), 7.74-7.61(\mathrm{~m}, 10 \mathrm{H}$, phenyl protons). ${ }^{1} \mathrm{H}$ NMR spectrum for complex 3 ( $\left.\delta \mathrm{ppm}\right): 10.40$ (d, $\left.1 \mathrm{H}, \mathrm{H}_{6^{\prime}}\right) ; 10.20\left(\mathrm{~d}, 1 \mathrm{H}, \mathrm{H}_{3^{\prime}}\right), 9.60\left(\mathrm{t}, 1 \mathrm{H}, \mathrm{H}_{4^{\prime}}\right) ; 8.98$ (d, $1 \mathrm{H}, \mathrm{H}_{5^{\prime}}$ ), $8.68\left(\mathrm{~s}, 1 \mathrm{H}, \mathrm{SO}_{3} \mathrm{H}\right), 8.90-7.51(\mathrm{~m}, 10 \mathrm{H}$, phenyl protons $) . J^{3} \mathrm{HG}^{\prime}, \mathrm{H}^{\prime}=$ $4.2 ; J^{3}{ }_{\mathrm{H}^{\prime}, \mathrm{H} 4^{\prime}}=7.8 ; J^{3} \mathrm{H}^{\prime}, \mathrm{H} 4^{\prime}=7.5 .{ }^{13} \mathrm{C}\left\{{ }^{1} \mathrm{H}\right\}$ NMR for the complex 3 $(\delta \mathrm{ppm}): 160.37\left(\mathrm{C}_{3}\right), 156.86\left(\mathrm{C}_{6}\right), 156.39\left(\mathrm{C}_{5}\right), 152.25\left(\mathrm{C}_{6^{\prime}}\right)$, $150.03\left(C_{2^{\prime}}\right), 138.65\left(C_{3^{\prime}}\right) 135.75\left(C_{4^{\prime}}\right), 135.64\left(C_{5^{\prime}}\right), 131.08-124.49$ (phenyl carbons).

\subsection{Biological studies}

\subsubsection{Chemicals and reagents}

Stock solutions of the compounds were prepared in DMSO and opportunely diluted in the culture medium. The final concentration of DMSO never exceeded $0.1 \%$ that is a concentration which had no discernible effect on employed cell lines in comparison with the control.

\subsubsection{Cell lines and culture conditions}

Human colon-rectal carcinoma HT29 and hepatoma HepG2 cells were grown as monolayers in RPMI 1640 medium, supplemented with $10 \%(\mathrm{v} / \mathrm{v})$ heat-inactivated foetal calf serum (FCS) and $2.0 \mathrm{mM}$ glutamine, at $37^{\circ} \mathrm{C}$ in a humidified atmosphere containing $5 \% \mathrm{CO}_{2}$. HepG2 culture medium also contained $1.0 \mathrm{mM}$ sodium pyruvate. The cells were seeded on 96-well plates $\left(10^{4}\right.$ cells/well $)$ for viability assay, and in 6 -wells plates $\left(3 \times 10^{5}\right.$ cells/wells) for flow cytometry and platinum uptake. After plating, cells were allowed to adhere overnight and then treated with the compounds or with the same amount of DMSO employed as vehicle for the Pt complex treatment (control cells).

\subsubsection{Cell viability assay}

The cytotoxic activity of the compounds was determined by the MTT quantitative colorimetric assay [13] capable of detecting viable cells. This method is based on the reduction of the 3-(4,5-dimethyl-2-thiazolyl)-2,5-diphenyl-2H-tetrazolium bromide (MTT) into purple formazan by mitochondrial dehydrogenases of living cells. Dye absorbance in viable cells was measured at $570 \mathrm{~nm}$ (test wavelength) with $630 \mathrm{~nm}$ (reference wavelength), using an ELISA microplate reader (OPSYS MR, Dynex Technologies) against lysis buffer as a blank. Cell survival was estimated as a percentage of the value of the vehicle-treated control.

\subsubsection{Cell cycle analysis}

The cell cycle phase distribution was evaluated by cytofluorimetric analysis. After treatment with the compounds, cells were harvested by trypsinization and resuspended in a hypotonic solution containing $50 \mu \mathrm{g} / \mathrm{ml}$ propidium iodide, $0.1 \%$ sodium citrate, $0.01 \%$ Nonidet P-40 and $10 \mu \mathrm{g} / \mathrm{ml}$ RNase A and incubated for 2$3 \mathrm{~h}$ at $4{ }^{\circ} \mathrm{C}$. The cell cycle profiles were analysed by Epics XL flow cytometer (Beckman Coulter) using Expo32 software. Percentage of cells in the subdiploid region was considered as an index of apoptosis.

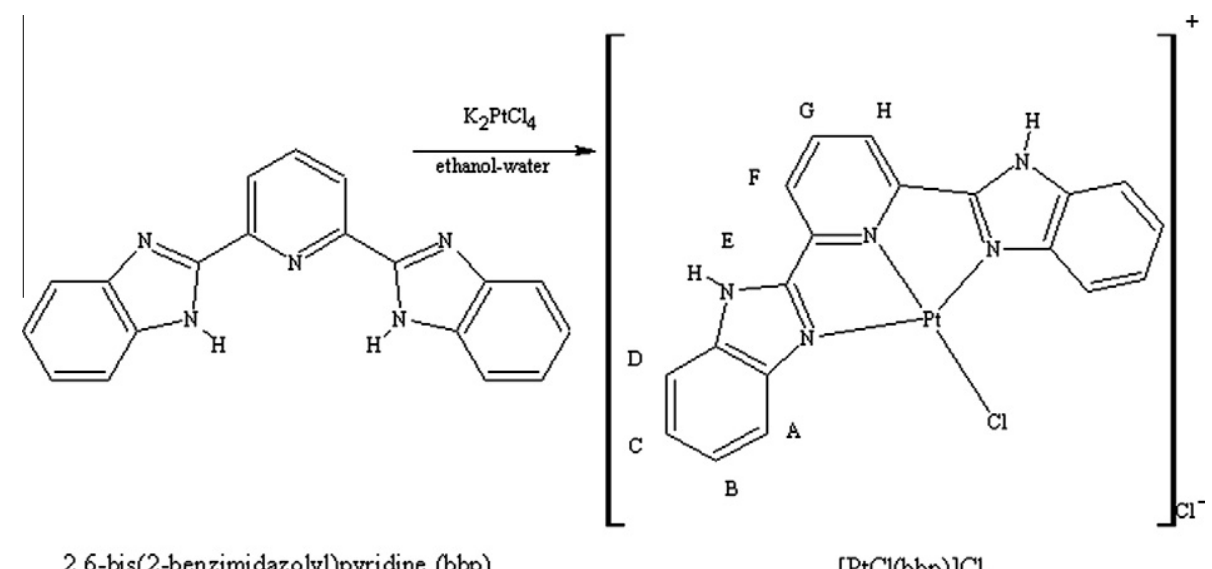

2,6-bis(2-benzimidazolyl)pyridine (bbp)

$[\mathrm{PtCl}(\mathrm{bbp})] \mathrm{Cl}$

Fig. 1. Structure of $[\mathrm{PtCl}(\mathrm{bbp})] \mathrm{Cl}$ complex (1) and numbering scheme of atoms.

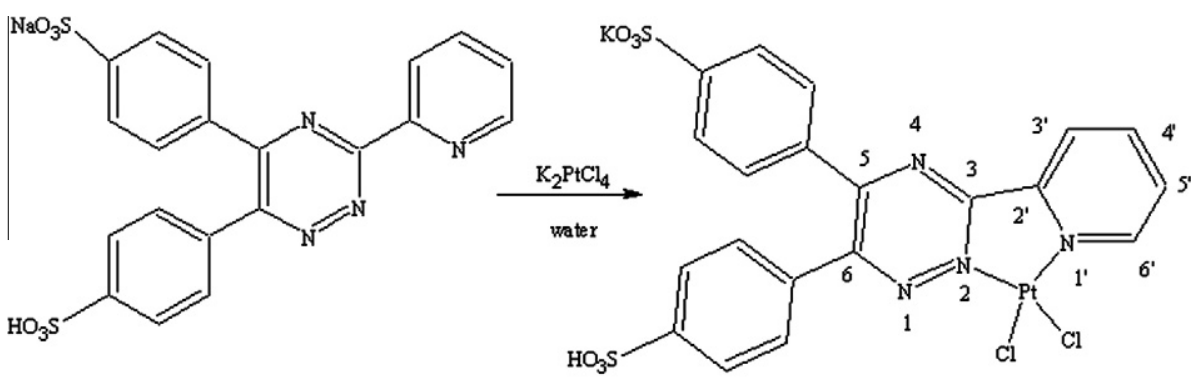

sodium 5,6-diphenyl-3(2'-pyridyl)-1,2,4-triazine-4",4"'-disulfonate

$\left[\mathrm{PtCl}_{2}(\mathrm{dptdn})\right]\left(\mathrm{H}_{2} \mathrm{O}\right)$

Fig. 2. Structure of $\left[\mathrm{PtCl}_{2}(\mathrm{dptdn})\right]\left(\mathrm{H}_{2} \mathrm{O}\right)$ complex (2) and numbering scheme of atoms. 
2.3.5. Measurement of mitochondrial transmembrane potential $\left(\Delta \psi_{m}\right)$ Mitochondrial transmembrane potential $\left(\Delta \psi_{\mathrm{m}}\right)$ was measured by using 3,3-dihexyloxacarbocyanine $\left(\mathrm{DiOC}_{6}\right.$ Molecular Probes, Eugene, OR), a lipophilic cationic fluorochrome which exclusively emits within the spectrum of green light and accumulates in the mitochondrial matrix under the influence of $\Delta \psi_{\mathrm{m}}$. After treatment, cells were incubated with $40 \mathrm{nM} \mathrm{DiOC}_{6}$ for $20 \mathrm{~min}$ at $37^{\circ} \mathrm{C}$, washed twice with PBS and analysed by flow cytometry on Beckman Coulter Epics XL flow cytometer with excitation and emission setting of 488 and $525 \mathrm{~nm}$, respectively. The percentage of cells showing a lower fluorescence, reflecting loss of mitochondrial transmembrane potential, was determined by comparison with untreated control using Expo32 software. Carbonyl cyanide m-chlorophenylhydrazone (CCCP, $50 \mu \mathrm{M})$, a protonophore which completely de-energises mitochondria by dissipating the transmembrane potential, was used as a positive control for maximum $\Delta \psi_{\mathrm{m}}$ disruption (not shown).

\subsubsection{Hoechst staining}

Chromatin condensation was detected by nuclear staining with Hoechst 33258. The cells were seeded in 96-well plates, fixed with ice-cold $\mathrm{MeOH} / \mathrm{AcOH}$ 3:1 for $10 \mathrm{~min}$ at room temperature, washed in phosphate buffer saline (PBS) and stained for $10 \mathrm{~min}$ in PBS containing 40\% paraformaldehyde and $10 \mu \mathrm{g} / \mathrm{ml}$ Hoechst 33258 in the dark for $10 \mathrm{~min}$. After staining, the samples were observed under a fluorescence microscope equipped with an automatic photomicrograph system (Leica, Germany).

\subsubsection{Total cellular platinum uptake measurement}

For platinum uptake studies [14], HT29 cells were incubated with the compounds at $10 \mu \mathrm{M}$ concentration. After $24 \mathrm{~h}$ the cells were washed three times with cold PBS (Phosphate Buffered Saline), collected by trypsinization and centrifuged at $1000 \mathrm{~g}$ for $5 \mathrm{~min}$. At the end the pellet was suspended in Milli-Q water, sonicated and the platinum content measured with a Perkin-Elmer 3100 graphite furnace atomic absorption spectrometer (GFAA). Instrumental settings were optimised in order to yield maximum sensitivity for platinum. The data were expressed as ng Pt per $\mathrm{mg}$ of cell proteins and were the results of three independent experiments \pm SD. Protein concentration was assayed by means of the method of Lowry [15].

\section{Results and discussion}

\subsection{Chemistry}

3.1.1. IR spectra of $[\mathrm{PtCl}(\mathrm{bbp})] \mathrm{Cl}(\mathbf{1}),\left[\mathrm{PtCl}_{2}(\mathrm{dptdn})\right]\left(\mathrm{H}_{2} \mathrm{O}\right)(\mathbf{2})$, [(dptdn)(dpt)Pt]Cl $\mathrm{Cl}_{2}\left(\mathrm{H}_{2} \mathrm{O}\right)(\mathbf{3})$ complexes

In all complexes, the absorption bands in the high frequency region which originate in the heterocyclic ring of the ligands, appear not to be metal sensitive [16].

In complex $1 \mathrm{~N}-\mathrm{H}$ stretching bands sharper than those of the free ligand are present, due to breaking of the ligand's tautomerism, indicating that the $\mathrm{N}-\mathrm{H}$ group was not involved in coordination.

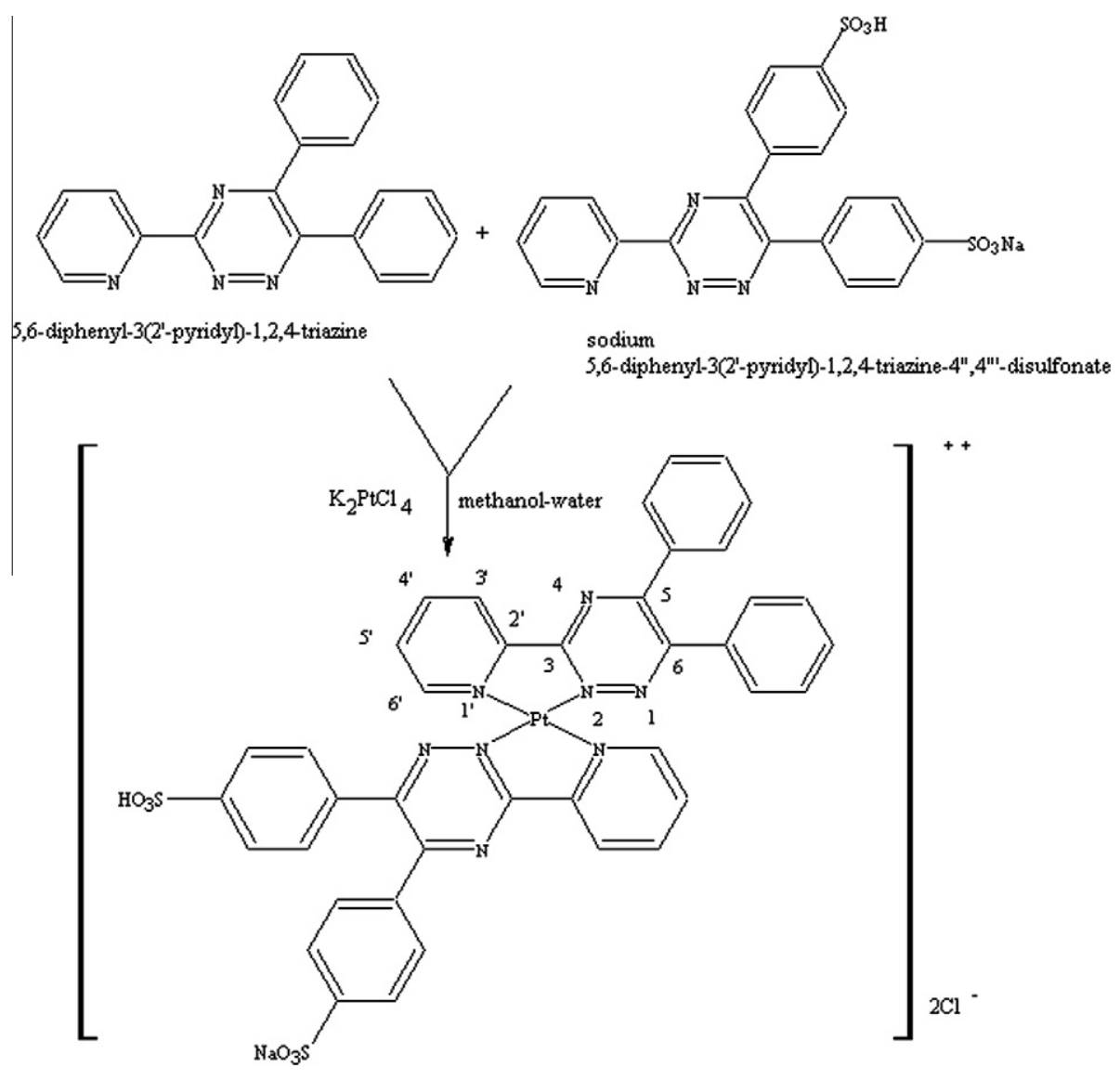

$[(\mathrm{dptdn})(\mathrm{dpt}) \mathrm{Pt}] \mathrm{Cl}_{2}\left(\mathrm{H}_{2} \mathrm{O}\right)$

Fig. 3. Structure of $[\mathrm{Pt}(\mathrm{dptdn})(\mathrm{dpt})] \mathrm{Cl}_{2}\left(\mathrm{H}_{2} \mathrm{O}\right)$ complex (3) and numbering scheme of atoms. 


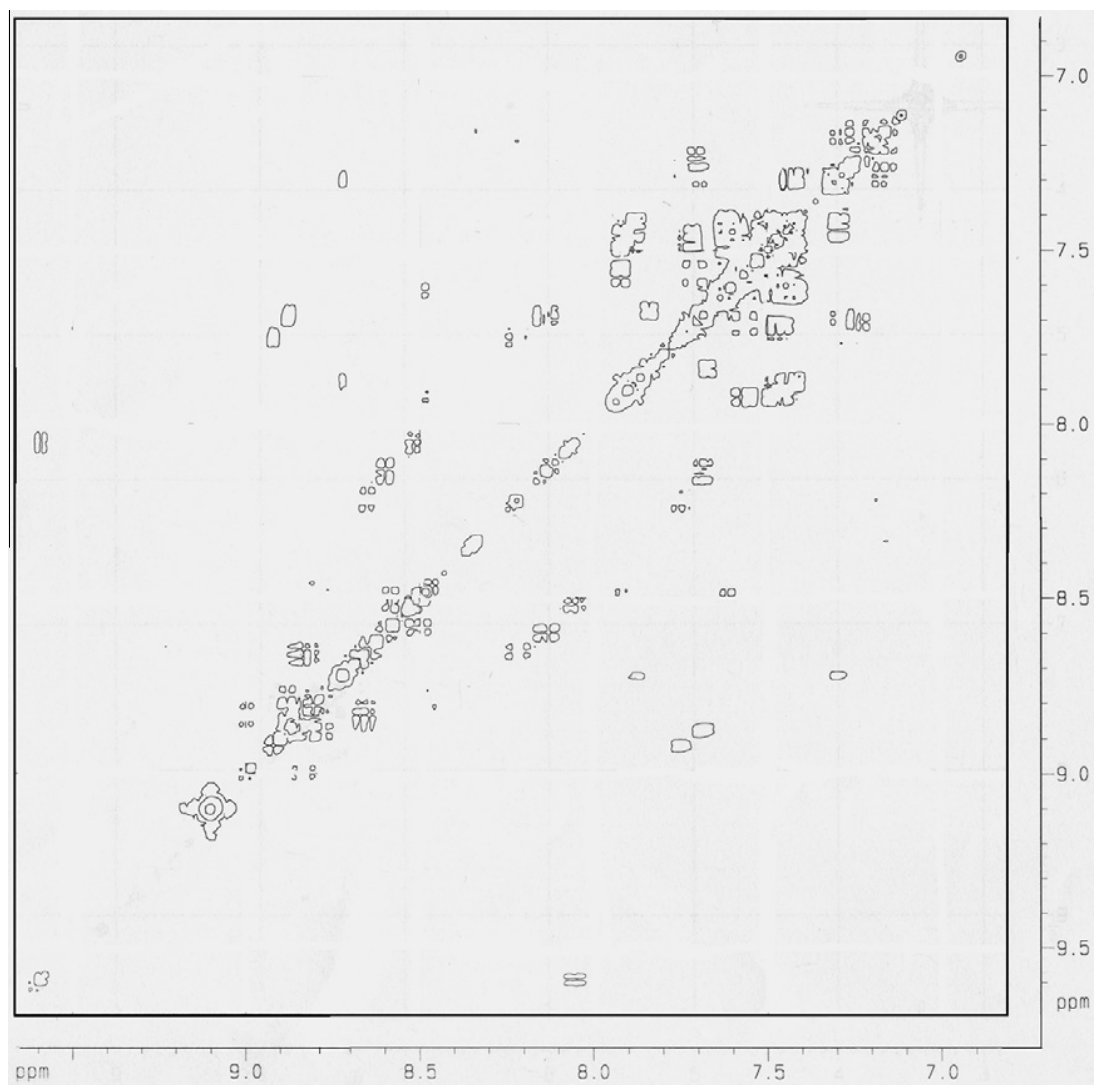

Fig. 4. ${ }^{1} \mathrm{H}-{ }^{1} \mathrm{H}$ COSY spectrum for $[\mathrm{Pt}(\mathrm{dptdn})(\mathrm{dpt})] \mathrm{Cl}_{2}\left(\mathrm{H}_{2} \mathrm{O}\right)$ complex (3).

Table 1

${ }^{1} \mathrm{H}$ NMR chemical shifts (ppm) for bbp ligand and complex $\mathbf{1}$ in DMSO- $\mathrm{d}_{6}$ at $25^{\circ} \mathrm{C}$.

\begin{tabular}{lcc}
\hline & bbp Ligand & Complex 1 \\
\hline $\mathrm{NH}$ & 13.06 & 10.16 \\
$\mathrm{H}_{\mathrm{F}}-\mathrm{H}_{\mathrm{H}}$ & 8.42 & 8.40 \\
$\mathrm{H}_{\mathrm{G}}$ & 8.23 & 8.30 \\
$\mathrm{H}_{\mathrm{A}}-\mathrm{H}_{\mathrm{D}}$ & 7.82 & 7.80 \\
$\mathrm{H}_{\mathrm{B}}-\mathrm{H}_{\mathrm{C}}$ & 7.40 & 7.45 \\
\hline
\end{tabular}

Coupling constants for the complex 1: $J_{\mathrm{HF}, \mathrm{HH}-\mathrm{HG}}^{3}=7.5 ; J_{\mathrm{HA}, \mathrm{HD}-\mathrm{HB}, \mathrm{HC}}^{3}=3.3 ;(\mathrm{J}$ in $\mathrm{Hz})$.

In complexes $\mathbf{2}$ and 3, stretching vibrations due to $v(\mathrm{C}=\mathrm{N})$ and of $v(\mathrm{~N}=\mathrm{N})$ of the ligand, are shown at lower values, supporting the notion that coordination of the triazine rings and the $\mathrm{N}$ atom of the pyridyl ring to the metal ion has taken place.

\subsection{2. ${ }^{1} \mathrm{H} \mathrm{NMR}$ of $[\mathrm{PtCl}(\mathrm{bbp})] \mathrm{Cl}(\mathbf{1}),\left[\mathrm{PtCl}_{2}(\mathrm{dptdn})\right]\left(\mathrm{H}_{2} \mathrm{O}\right)(\mathbf{2})$ and $[(\mathrm{dptdn})(\mathrm{dpt}) \mathrm{Pt}] \mathrm{Cl}_{2}\left(\mathrm{H}_{2} \mathrm{O}\right)(\mathbf{3})$ complexes}

The reaction scheme with the numbering of protons used for the ${ }^{1} \mathrm{H}$ NMR is shown in Figs. $1-3$. The resonances of the pyridine groups coordinated to platinum are noticeably different from those of non-coordinating pyridines and are shifted to higher frequencies whilst ${ }^{3} J_{\mathrm{H}-\mathrm{H}}$ coupling constants for the complex are very similar to those of the free ligand helping the assignments. Sharpness of resonances gives an indication that neither oligomerization of complexes nor fluxionality is present. A ${ }^{1} \mathrm{H}-{ }^{1} \mathrm{H}$ COSY experiment was carried out and the resulting spectrum for the mixed ligand complex $[(\mathrm{dptdn})(\mathrm{dpt}) \mathrm{Pt}] \mathrm{Cl}_{2}\left(\mathrm{H}_{2} \mathrm{O}\right) 3$ is presented in Fig. 4 which shows the connectivities and couplings reported hereafter.

In complex 1 the two benzimidazole and pyridine rings are expected to be nearly in the same plane; the three $\mathrm{N}$ atoms of the ligand and the central Pt atom forming a good plane. The $\mathrm{N}-\mathrm{H}$
Table 2

${ }^{1} \mathrm{H}$ NMR chemical shifts (ppm) for dptdn, dpt ligands and complex 2 and $\mathbf{3}$ in DMSO$\mathrm{d}_{6}$ at $25^{\circ} \mathrm{C}$.

\begin{tabular}{lllll}
\hline & dptdn Ligand & dpt Ligand & Complex 2 & Complex 3 \\
\hline $\mathrm{H}_{6^{\prime}}$ & 8.94 & 9.01 & 10.49 & 10.40 \\
$\mathrm{H}_{3^{\prime}}$ & 8.80 & 8.74 & 9.71 & 10.20 \\
$\mathrm{H}_{4^{\prime}}$ & 8.42 & 8.28 & 8.93 & 9.60 \\
$\mathrm{SO}_{3} \mathrm{H}$ & $8.34-8.21$ & & 8.43 & 8.68 \\
$\mathrm{H}_{5^{\prime}}$ & 7.93 & 8.83 & 8.76 & 8.98 \\
Phenyl protons & $7.74-7.28$ & $7.74-7.61$ & $7.69-7.94$ & $8.90-7.51$ \\
\hline
\end{tabular}

Coupling constants for the complex $2: J^{3} \mathrm{H}^{\prime}, \mathrm{H}^{\prime}=4.2 ; J^{3} \mathrm{H}^{\prime}, \mathrm{H} 4^{\prime}=8.2 ; J^{3} \mathrm{H}^{\prime}, \mathrm{H} 4^{\prime}=8.0$ and complex 3: $J_{\mathrm{H}^{\prime}, \mathrm{H} 5^{\prime}}^{3}=4.2 ; J^{3}{ }_{\mathrm{H} 3^{\prime}, \mathrm{H} 4^{\prime}}=7.8 ; J^{3}{ }_{\mathrm{H}^{\prime}, \mathrm{H} 4^{\prime}}=7.5$.

benzimidazole signals are indicative of the complex formation. There are two magnetically equivalent benzimidazole $\mathrm{N}-\mathrm{H}$ hydrogens at $\delta=10.16$ that have undergone an upfield shift. Coordination is associated with the concomitant both positive and negative induced shifts of proton resonances of aromatic rings. According to literature data [9] these effects are due to electron donation from the ligand to the metal via $\sigma$-bond, metal electron $\pi$-back donation, van der Waals interaction and magnetic anisotropy of ring currents.

The NMR data for free ligand and the complex $\mathbf{1}$ are reported in Table 1 . The close similarity of ${ }^{1} \mathrm{H}$ NMR data for the complex under investigation with those reported for palladium halocomplexes suggests a similar geometry and coordination [9].

The coordination mode of ionic mononuclear complexes $\mathbf{2}$ and $\mathbf{3}$ were analogously determined. The data for free ligand and the complexes $\mathbf{2}$ and $\mathbf{3}$ are reported in Table 2 which closely agree with the spectra in $\mathrm{CD}_{2} \mathrm{Cl}_{2}$ reported in the literature [10-11]. ${ }^{13} \mathrm{C}\left\{{ }^{1} \mathrm{H}\right\}$ NMR for the complexes $\mathbf{2}$ and $\mathbf{3}$ is reported in Table 3 . In the spectra of complex 2 the protons of the pyridyl rings appear as a set of 
Table 3

${ }^{13} \mathrm{C}\left\{{ }^{1} \mathrm{H}\right\}$ NMR chemical shifts (ppm) for the complex 2 and 3 in DMSO- $\mathrm{d}_{6}$.

\begin{tabular}{lll}
\hline & Complex 2 & Complex 3 \\
\hline$C_{3}$ & 157.86 & 160.37 \\
$C_{6}$ & 157.25 & 156.86 \\
$C_{5}$ & 156.47 & 156.39 \\
$C_{6^{\prime}}$ & 149.03 & 152.25 \\
$C_{2^{\prime}-3^{\prime}}$ & 148.94 & $150.03-138.65$ \\
$C_{4^{\prime}}$ & 147.25 & 135.75 \\
$C_{5^{\prime}}$ & 143.15 & 135.64 \\
Phenyl carbons & $134.82-125.49$ & $131.08-124.49$ \\
\hline
\end{tabular}

four associated resonances well defined from the protons of the two phenyl rings, similar to the spectra of $\mathrm{Zn}(\mathrm{dpt}) \mathrm{Cl}_{2}$ complexes [11].

Coordination of dptdn to $\mathrm{Pt}(\mathrm{II})$ causes the displacement of the pyridyl rings resonances down field with respect to the uncoordinated ligand. Therefore the coordination of the ligand in complex $\mathbf{2}$ involves the nitrogen atoms of the pyridyl ring and N-2 of the triazine ring. As reported for similar complexes of ruthenium(II) [17] the coordination mode of the triazine ring occurs through $\mathrm{N}-2$ atom, since in this case the steric hindrance between the phenyl groups and pyridyl ring is minimised. Whilst the presence of negatively charged sulphonic groups in the structure of complex $\mathbf{2}$ is beneficial for solubility of the complex, repulsive interactions through sulphonate groups and DNA phosphate groups are probably drastically reducing the drug effectiveness towards DNA, the complex being inactive [18].

The mixed ligand complex $\left[(\mathrm{dptdn})(\mathrm{dpt}) \mathrm{Pt} \mathrm{Cl}_{2} \mathbf{3}\right.$ arises from a tentative synergic design of a complex bringing a "innocent" ligand (dptdn) and an active one (dpt) together. According to a published procedure [6] we synthesized the $\mathrm{Pt}(\mathrm{dpt}) \mathrm{Cl}_{2}$ complex, performing the MTT test on HT29 and HepG2 cancer cell lines for biological activity; being the compound active, we proceeded to synthesize the mixed ligand complex.

The two coordinated dpt and dptdn moieties are symmetrically bonded to the $\mathrm{Pt}(\mathrm{II})$ centre and are magnetically equivalent. The protons of the two phenyl rings appear in the remaining part of the spectra as two sets of multiplets, without being affected upon complexation. Noticeably coordinated triazine and pyridyl resonances are shifted to higher frequencies relative to resonances in the free ligands. The pyridyl ring protons of the free ligand dpt and dptdn suffer a clear downfield shift on coordination; the strongest shift corresponding to the $\mathrm{H}-6$ ' proton. The proposed structures take advantage of the X-ray structures of similar $\mathrm{LPtCl}_{2}$ and $\left[\mathrm{L}_{2} \mathrm{Pt}\right] \mathrm{Cl}_{2}$ complexes [L= substituted 3-(pyridine-2'-yl)-1,2,4-triazine] [6]. In our complexes we assume that the two phenyl rings of the triazine moiety are not coplanar with the triazine plane, in contrast the pyridyl and triazine rings are expected to be almost
Table 4

$\mathrm{IC}_{50}(\mu \mathrm{M})$.

\begin{tabular}{lll}
\hline & HT29 cells & HepG2 cells \\
\hline cis-DDP & 58 & 65 \\
{$[\mathrm{PtCl}(\mathrm{bbp})] \mathrm{Cl}$} & 22 & 26 \\
{$[(\mathrm{dptdn})(\mathrm{dpt}) \mathrm{Pt}] \mathrm{Cl}_{2}\left(\mathrm{H}_{2} \mathrm{O}\right)$} & 23 & 24 \\
\hline
\end{tabular}

coplanar. The mixed ligand complex $\mathbf{3}$ is characterised by an overall positive charge and four non-labile $\mathrm{N}$ bonds.

\subsection{Biology}

\subsubsection{Platinum complexes impair HT29 and HepG2 cell viability}

To examine the effect of the novel mononuclear platinum complexes, in comparison with that exerted by cisplatin, on human HT29 colorectal carcinoma and HepG2 hepatocarcinoma cells, monolayer cultures were treated for $24 \mathrm{~h}$ with various concentrations $(5-50 \mu \mathrm{M})$ of the drugs and the viability was evaluated by MTT assay to measure mitochondrial enzyme activity, as reported in Section 2 [13]. Fig. 5 shows that both $[\mathrm{PtCl}(\mathrm{bbp})] \mathrm{Cl} \mathbf{1}$ and $[(\mathrm{dptdn})(\mathrm{dpt}) \mathrm{Pt}] \mathrm{Cl}_{2}\left(\mathrm{H}_{2} \mathrm{O}\right) \mathbf{3}$ clearly reduced cell viability in a dose-dependent manner and their activity was higher than that shown by cisplatin. In particular, at the concentration of $50 \mu \mathrm{M}$ the reduction of cell viability, induced by the two compounds, was at a range of about $60-70 \%$. On the contrary, the $\left[\mathrm{PtCl}_{2}(\mathrm{dptdn})\right]\left(\mathrm{H}_{2} \mathrm{O}\right) 2$ complex was almost inefficacious. The marked cytotoxic activity of complexes $\mathbf{1}$ and $\mathbf{3}$ was confirmed by the values of IC50, clearly lower than that of cisplatin (Table 4).

Experiments performed to assay the activity of free ligands used to synthesize the $\mathrm{Pt}(\mathrm{II})$ complexes demonstrated that these ligands were unable to exert any inhibitory activity (not shown). Fig. 6 reports the effects of the two active Pt(II) complexes or cisplatin on HT29 cell cycle distribution as determined by flow cytometric analysis after staining of DNA with propidium iodide. Complexes 1 and 3, at concentration $25 \mu \mathrm{M}$ induced after $24 \mathrm{~h}$ of treatment a marked accumulation of cells (about 40\%) in the subG0/G1 phase of cell cycle which is representative of cells with fragmented DNA. At this concentration cisplatin was less active. Similar results were obtained with HepG2 cells (not shown). Furthermore, under the same experimental conditions, the study of mitochondrial transmembrane potential $\left(\Delta \psi_{\mathrm{m}}\right)$, using the lipophilic cationic fluorochrome $\mathrm{DiOC}_{6}$ and flow cytometry analysis (Fig. 7), shows that the two active compounds $\mathbf{1}$ and $\mathbf{3}$ induced in HT29 cells a significant decrease in $\mathrm{DiOC}_{6}$ uptake, indicating a loss of $\Delta \psi_{\mathrm{m}}$. The membrane potential decreased by about $40 \%$ in the presence of the two compounds and by about $20 \%$ with cisplatin.

We next assessed whether the cytotoxic effect of the active compounds was associated with the induction of apoptosis. Results of the Hoechst 33258 staining performed in HT29 cells treated
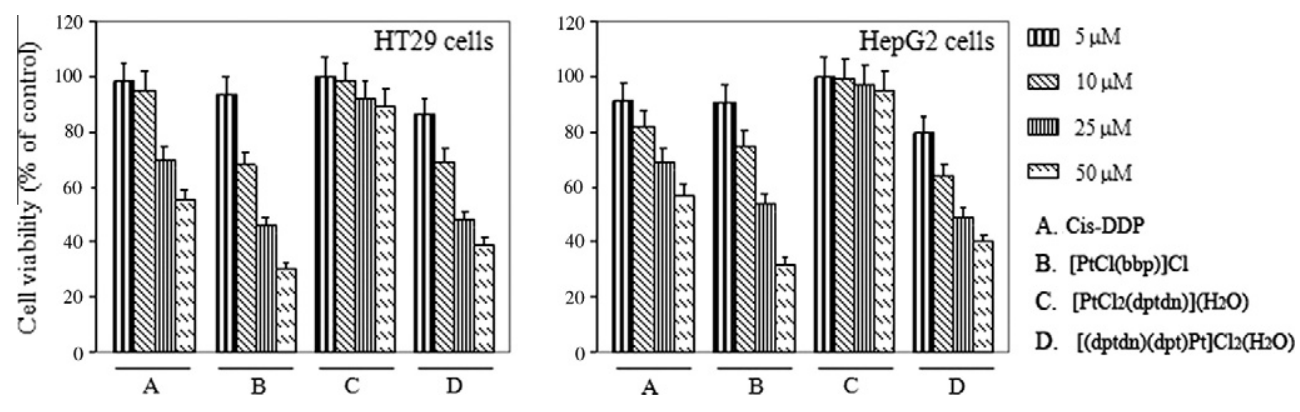

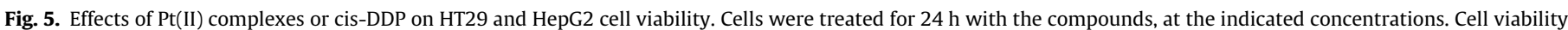

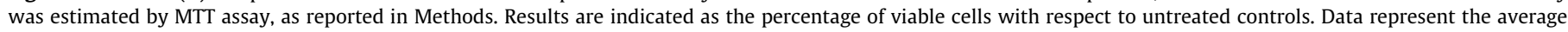
\pm S.D. of six independent experiments performed in triplicate. 

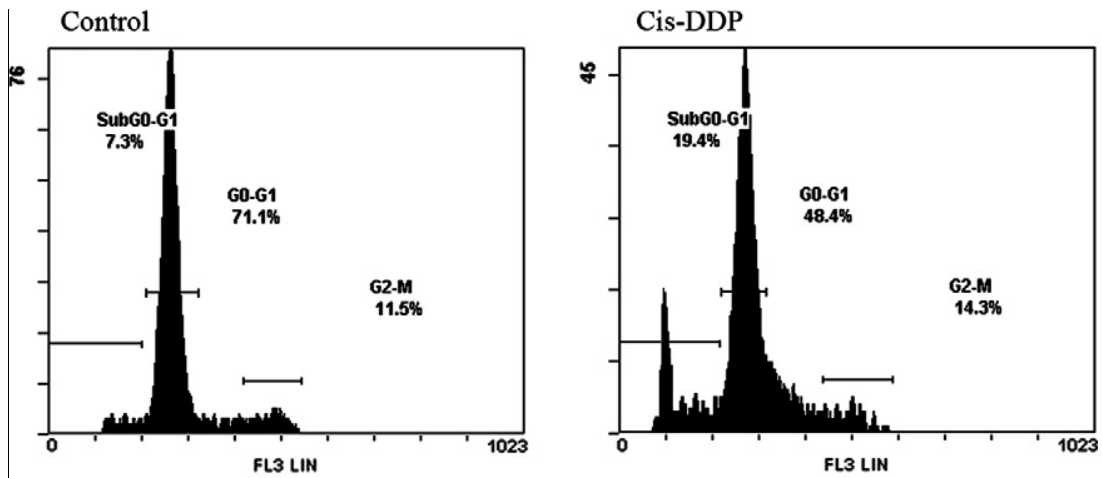

$[\mathrm{PtCl}(\mathrm{bbp})] \mathrm{Cl}$

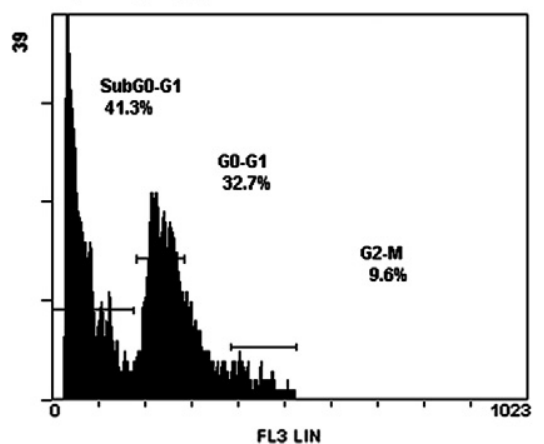

$[(\mathrm{dptdn})(\mathrm{dpt}) \mathrm{Pt}] \mathrm{Cl}_{2}\left(\mathrm{H}_{2} \mathrm{O}\right)$

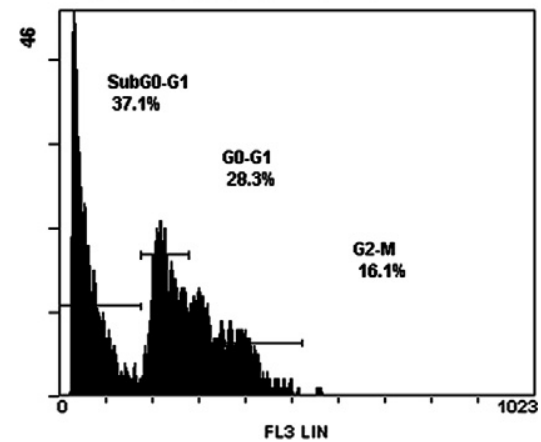

Fig. 6. Effects of Pt(II) complexes or cis-DDP on cell cycle distribution. Flow cytometric analysis of cell cycle distribution of HT29 cells after incubation with $25 \mu \mathrm{M}$ of the compounds, for $24 \mathrm{~h}$. Cells were stained with propidium iodide as described in Section 2. The percentage of cells in the different phases of the cycle was calculated using Expo32 software. Data are representative of four experiments with similar results.

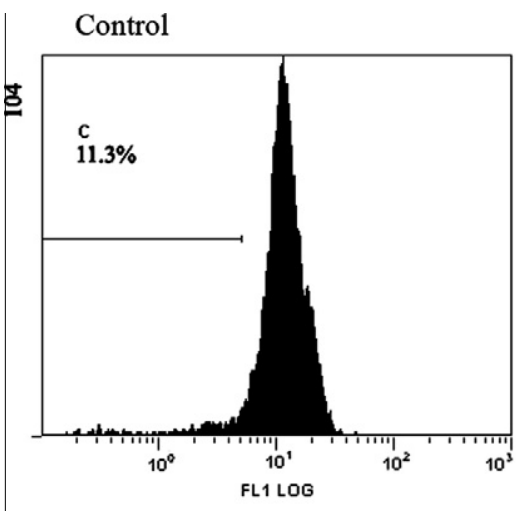

$[\mathrm{PtCl}(\mathrm{bbp})] \mathrm{Cl}$

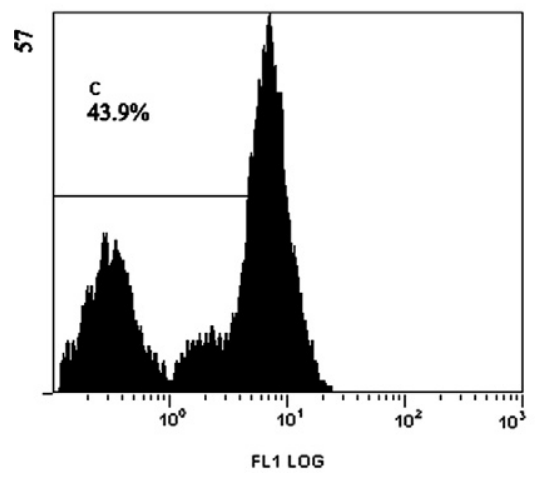

Cis-DDP

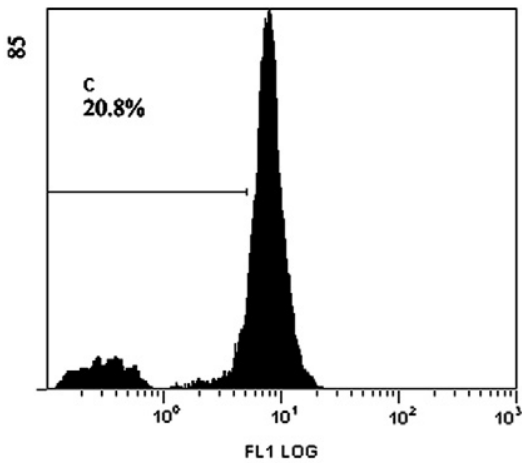

$[(\mathrm{dptdn})(\mathrm{dpt}) \mathrm{Pt}] \mathrm{Cl}_{2}\left(\mathrm{H}_{2} \mathrm{O}\right)$

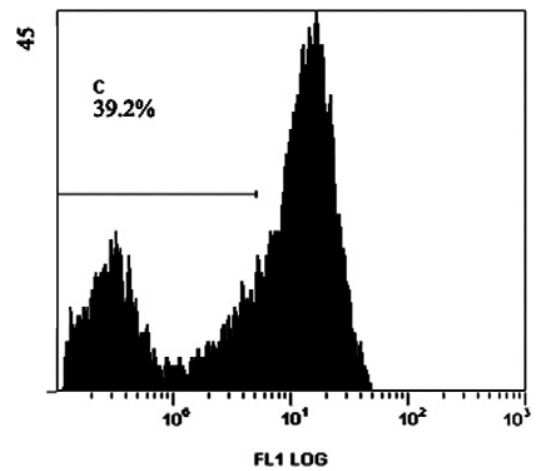

Fig. 7. Effects of Pt(II) complexes or cis-DDP on dissipation of mitocondrial transmembrane potential $\left(\Delta \psi_{\mathrm{m}}\right)$ in HT29 cells. After treatment with $25 \mu \mathrm{M}$ of the compounds for $24 \mathrm{~h}$ cells were stained with the lipophilic cationic fluorochrome $\mathrm{DiOC}_{6}$ as reported in Methods. Quantification of $\Delta \psi_{\mathrm{m}}$ was performed by flow citometry using Expo32 software. Data are representative of three separate experiments with similar results. 

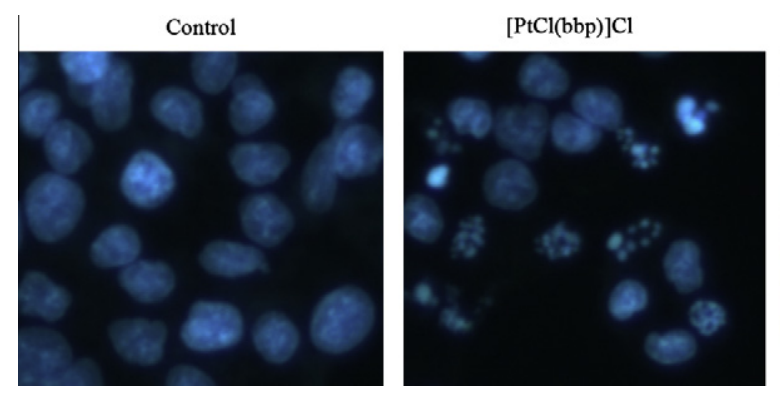

$[(\mathrm{dptdn})(\mathrm{dpt}) \mathrm{Pt}] \mathrm{Cl}_{2}\left(\mathrm{H}_{2} \mathrm{O}\right)$

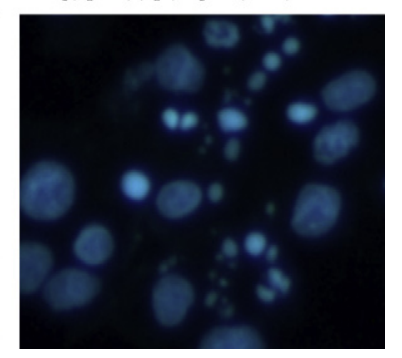

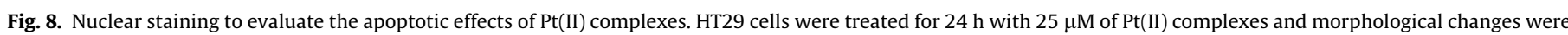

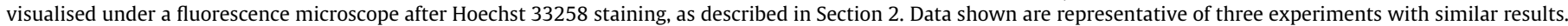

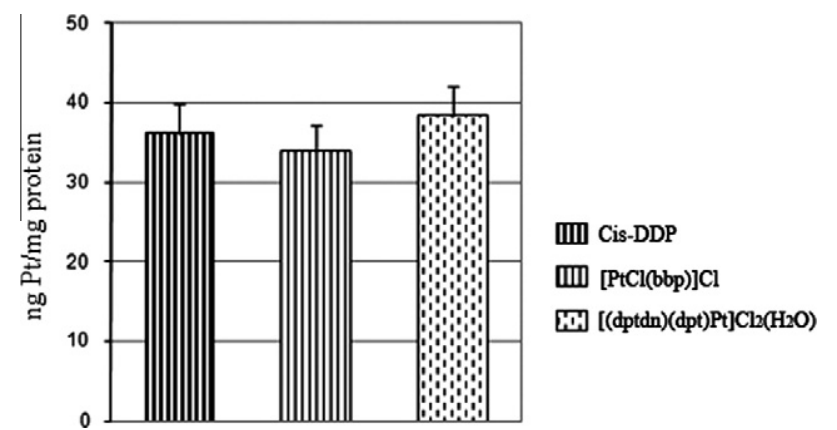

Fig. 9. Platinum intracellular accumulation after incubation with $\mathrm{Pt}(\mathrm{II})$ complexes or cis-DDP. HT29 cells were treated for $24 \mathrm{~h}$ with the compounds at $10 \mu \mathrm{M}$ concentration. At the end intracellular Pt was quantified by GFAA as described in Methods. The results are representative of three independent experiments.

with $25 \mu \mathrm{M}$ of complexes 1 and 3, for $24 \mathrm{~h}$, demonstrated apoptotic features such as nuclear shrinkage, chromatin condensation or fragmentation (Fig. 8).

In order to better understand the cytotoxic activity of the new mononuclear platinum complexes, with respect to cisplatin, we have determined cellular platinum uptake on HT29 cells after $24 \mathrm{~h}$ continuous exposure with $10 \mu \mathrm{M}$ compounds. The amount of intracellular platinum, evaluated by GFAA, for Pt(II) complexes gave similar values to those obtained for cisplatin (Fig. 9). Therefore, these results demonstrated that the different cytotoxic effects exerted by the new Pt(II) complexes and cisplatin could not be explained in terms of different platinum uptake.

\section{Conclusions}

A series of new Pt(II) "non classical" mononuclear complexes $\mathbf{1}$, $\mathbf{2}$ and 3, both ionic $\mathbf{1}$ and $\mathbf{3}$ and neutral $\mathbf{2}$ with heterocyclic ligands have been synthesized and characterised. The coordination of Pt(II) in $\mathbf{1}$ has been advanced to take place through three $\mathrm{N}$-atoms, one of pyridine and two of benzimidazole moieties, that originate a highly ionic symmetric complex. The neutral asymmetric complex 2 contains a bifunctional $\mathrm{PtCl}_{2}$ moiety bonded in a cis position to two $\mathrm{N}$ atoms of heterocyclic ligand with a cisplatin similar coordination. The ionic complex 3 contains two different heterocyclic dptdn and dpt ligands with $\mathrm{Pt}(\mathrm{II})$ ion bonded to four $\mathrm{N}$ atoms of the ligands forming a square planar complex. Two of the novel mononuclear platinum complexes, $\mathbf{1}$ and $\mathbf{3}$, synthesized in our laboratory, show a potent cytotoxic activity in HT29 and HepG2 cancer cell lines. The marked cytotoxic activity of $\mathbf{1}$ and $\mathbf{3}$ complexes was confirmed by the values of IC50, clearly lower than that of cisplatin. On the contrary, the complex $\mathbf{2}$ was almost ineffective. Flow cytometric analysis and fluorescence microscopy demonstrated that the complexes $\mathbf{1}$ and $\mathbf{3}$ induced apoptotic cells death as evidenced by a marked accumulation of cells in the subG0/G1 phase of cell cycle, loss of mitochondrial transmembrane potential $\left(\Delta \psi_{\mathrm{m}}\right)$ and morphological changes, respectively. A study on intracellular Pt uptake in HT29 cell line, that is the amount of intracellular metal corresponding to the quantity of drug present inside the cell, has been also performed, showing that the different in vitro cytotoxic effects of the novel complexes reported in this work and of cisplatin could not be explained in terms of platinum uptake, but based on different phamacodynamics. On the basis of the planar structure of the compounds and of their positive charge, we hypothesise that the exerted cytotoxic activity can explained by possible intercalative interactions with DNA.

This observation suggests that the mechanism underlying the antitumor activity of complexes $\mathbf{1}$ and $\mathbf{3}$ might be different from that of cisplatin and very close to those reported by us for polynuclear ionic platinum complexes with triazine derived heterocycles $[19,20]$.

\section{Acknowledgements}

Financial support by the Ministero dell'Istruzione, dell'Università e della Ricerca, Rome and by the Università degli Studi di Palermo is gratefully acknowledged.

\section{References}

[1] K.R. Barnes, S.J. Lippard, Metal ions in biological systems, in: A. Siegel, H. Siegel (Eds.), Fontis Media S.A. and Marcel Dekker, vol. 42, Basel, New York, 2004, pp. 143.

[2] D. Wang, S.J. Lippard, Nat. Rev. Drug Discovery 4 (2005) 307.

[3] J. Reedijk, Platinum Met. Rev. 52 (2008) 2.

[4] N. Margiotta, G. Natile, F. Capitelli, F.P. Fanizzi, A. Boccarelli, P. De Rinaldis, D. Giordano, M. Cosuccia, J. Inorg. Biochem. 100 (2006) 1849.

[5] C. Mock, I. Puscasu, M.J. Rauterkus, G. Tallen, J.E.A. Wolff, B. Krebs, Inorg. Chim Acta 319 (2001) 109 (and references therein).

[6] S. Komeda, M. Luzt, A.L. Spek, M. Chikuma, J. Reedijk, Inorg. Chem. 39 (2000) 4230.

[7] V. Maheshwari, D. Bhattacharyya, F.R. Fronczek, P.A. Marzilli, L.G. Marzilli, Inorg. Chem. 45 (2006) 7182.

[8] W. Schöniger, Mikrochim. Acta (1955) 123.

[9] J.Q. D'souza, Y.C. Reddy, V. Gayathri, N.M.N. Gowda, Transition Met. Chem. 29 (2004) 113.

[10] J. Granifo, Polyhedron 14 (1995) 153.

[11] V. Berèau, J. Marrot, C.R. Chim. 8 (2005) 1087.

[12] W.J. Geary, Coord. Chem. Rev. 7 (1971) 81 (and references therein).

[13] T. Mosmann, J. Immunol. Methods 65 (1983) 55.

[14] E. Gabano, D. Colangelo, A.R. Grezzi, D. Osella, J. Inorg. Biochem. 102 (2008) 629.

[15] O.H. Lowry, N.J. Rosebrough, A.L. Farr, R.J. Randall, J. Biol. Chem. 193 (1951) 265.

[16] K. Nakamoto (Ed.), Infrared and Raman Spectra of Inorganic and Coordination Compounds, Part B: Applications in Coordination, Organometallic and Bioinorganic Chemistry, fifth ed., A Wiley-Interscience Publication, USA, 1997.

[17] H. Deng, J. Li, K.C. Zheng, Y. Yang, H. Chao, L.N. Ji, Inorg. Chim. Acta 358 (2005) 3430 .

[18] S.A. De Pascali, D. Mingoni, P. Papaia, A. Muscella, S. Marsignante, A. Ciccarese, F.P. Fanizzi, Dalton Trans. (2006) 5077.

[19] S. Rubino, P. Portanova, A. Albanese, G. Calvaruso, S. Orecchio, G. Fontana, G.C. Stocco, J. Inorg. Biochem. 101 (2007) 1473.

[20] S. Rubino, P. Portanova, A. Girasolo, G. Calvaruso, S. Orecchio, G.C. Stocco, Eur. J. Med. Chem. 44 (2009) 1041. 